\title{
Production of Cost Effective and High Strength Geopolymer Concrete Masonry Blocks
}

Shabarish Patil*, Krishna Rathi, Md Osama Budihal, Ashwini Dhadekar, Dixita Salecha

Department of Civil Engineering, KLE Institute of Technology, Hubballi, opposite to Airport, Gokul Road, Hubballi - 580 030, Karnataka, India.

ABSTRACT: Building block represents one of the vital materials in construction industry, the increased demand and requirement of building material has made the industry to grow vertically, the innovation and change in concrete block industry plays important role to produce cost effective, durable and sustainable building block which is the need of hour. The production of large amount of fly-ash requires land in the form of ash ponds. The challenge arises in utilizing this fly-ash in the production of sustainable building materials. The present experimental study involves the production of Geopolymer concrete blocks from fly ash, GGBS (Ground granulated blast furnace slag), slag sand, coarse aggregate, sodium silicate, sodium hydroxide to make the concrete block cost effective, high strength, sustainable and durable. The block is cast with different percentages of fly ash (16.8\%), GGBS (5.2\%), slag sand (19.2\%), manufactures sand (12.8\%), coarse Aggregate (35\%), Alkaline solution (6\%), Water (5\%). The tests on specimen conducted are compressive strength, water absorption test, and dimension test on respective ambient/oven curing of 3 and 7 days. The cost estimation is also done for the geopolymer concrete block. The blocks produced are found to be high in strength, cost effective, durable and sustainable as compared to conventional cement concrete blocks and thus it makes them to use commercially in construction industry.

KEYWORDS: Fly-ash, GGBS, slag sand, durable, cost effective, compressive strength

https://doi.org/10.29294/IJASE.5.4.2019.1099-1105

(c) 2019 Mahendrapublications.com, All rights reserved

\section{INTRODUCTION}

The production of cement releases large amount of carbon dioxide $\left(\mathrm{CO}_{2}\right)$ to the atmosphere that significantly contributes to greenhouse gas emissions. It is estimated that one ton of $\mathrm{CO}_{2}$ is released into the atmosphere for every ton of Ordinary Portland cement (OPC) produced [4]. In view of this, there is a need to develop sustainable alternatives to conventional cement, utilizing the cementitious properties of industrial by-products such as fly ash, GGBS and slag sand in replacement to river sand. A significant quantity of fuel is utilized in making conventional bricks making them non sustainable [11]. In this present work, an attempt is made to make the geopolymer concrete blocks as replacement to the conventional burnt brick with more added benefits. There is strong need to adopt sustainable technologies. Approximately half of the electricity consumed in the world is by burning coal which also has a byproduct fly-ash (a cementitious material) that is left out as waste. Disposal of this waste has become an emerging problem. As of which we are using geopolymer blocks in which cement is been replaced by fly ash which aids in both issues i.e. reducing of environmental problem caused by cement \& bricks as well as decreases problem of disposal of fly-ash [3,8,17].

Geo-polymerization is a technology that relies on the chemical reaction of amorphous silica \& alumina rich solids with alkaline solution to form amorphous to semi-crystalline alumino-silicate inorganic polymer or geopolymers [1]. In the construction sector, geopolymers represent an eco friendly, low cost and low power consumption alternative of traditional inorganic matrices \& composites due to the use of industrial by-products as solid precursors \& low calcinations temperature. Compared to Portland cement, they exhibit superior engineering properties $[2,7]$.

It is in this context an effort is made to produce GPC block (400 mm X $150 \mathrm{~mm} \mathrm{X} 150 \mathrm{~mm}$ ) using fly ash and GGBS as binder with compressive strength above 4 $\mathrm{MPa}$. The prime factor or parameter considered in this work is alkaline solution in which the molarity of sodium hydroxide is taken as 6M. The water absorption test is carried out for the specimens. The detailed cost estimation per $\mathrm{m}^{3}$ of the block as well as cost per block is done and it is found that the geopolymer blocks are cheaper than conventional cement concrete blocks in the local market $[8,9]$.

\section{METHODOLOGY}

The methodology is explained in the following Figure 1. The nominal dimensions of concrete block as per IS 2185 (part 1): 2005 shall be as follows:

Length: 400, 500 or $600 \mathrm{~mm}$

Height: 200 or $100 \mathrm{~mm}$

Width : 50,75, 100, 150,200, 250 or $300 \mathrm{~mm}$.

*Corresponding Author: shabarish6933@gmail.com

Received: 21.03.2019 Accepted: 20.04.2019

Published on: 27.05.2019 
The size of the block adopted is: Length: $400 \mathrm{~mm}$, Height: $150 \mathrm{~mm}$ and Width: $150 \mathrm{~mm}$ as shown in

Figure 2 [18].
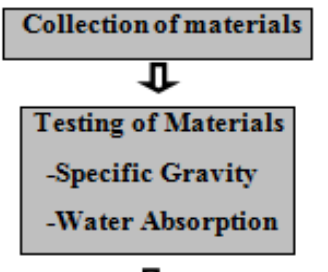

I

Mix Design

I

Casting of specimen

I
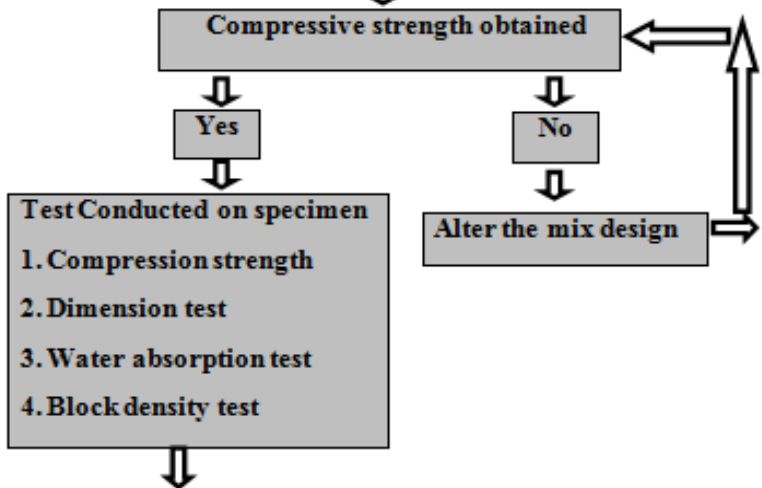

$\Downarrow$

Results and discussion

Figure 1. Methodology of the present research work

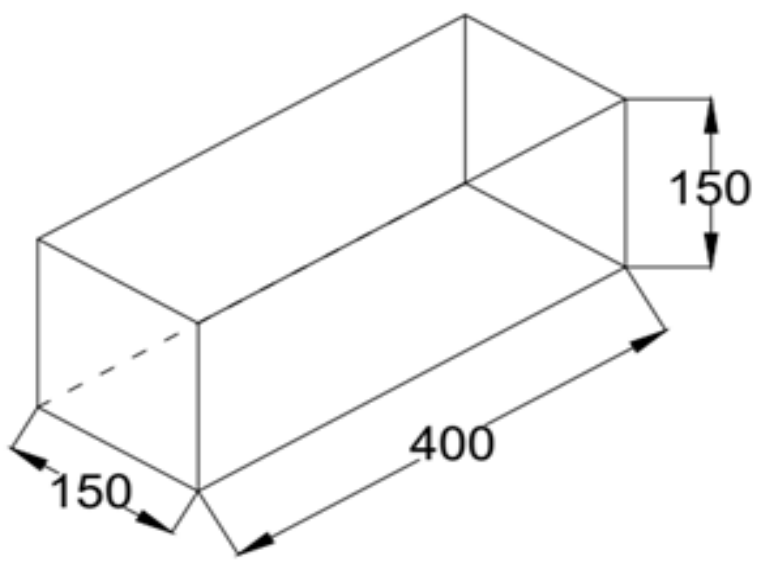

Figure 2: Dimensions of the masonry concrete block (all dimensions are in $\mathrm{mm}$ )

\section{MATERIALS}

Fly ash which is obtained from Kudagi Thermal Power Station, India and GGBS obtained from JSW steel, Bellary, India. Locally available slag sand and M-sand were used as fine aggregates, coarse aggregates are used in this present research work. A combination of $6 \mathrm{M}$ sodium hydroxide and sodium silicate in the ratio of 2.0 was used as solution for activation. Sodium hydroxide flakes of commercial grade were used in present work. Sodium silicate also known as water

\section{Sabarish Patil et al.,}


glass is of industrial grade with $\mathrm{SiO}_{2}$ as $34.8 \%$ by mass and $\mathrm{Na}_{2} \mathrm{O}$ as $16.51 \%$ \& water as $48.69 \%$ [6]. Water used for the mix is of potable quality. The nomenclature KF-60 is Kudagi Fly-ash, used as $60 \%$ in volume of total binding agent.

\section{EXPERIMENTAL WORK}

4.1 Mix Design for Optimum Fly-ash to GGBS Ratio GPC is produced with many materials like fly-ash, GGBS and binding agents. The intention is to produce the block with optimum fly-ash to GGBS ratio to optimize the cost and environmental impact. Various trials with different ratios of fly-ash to GGBS are cast, if desired compressive strength is obtained then various tests are carried out. The Water to geo polymer solids ratio is fixed as 0.38 [8]. The Alkaline solution to Binder ratio is fixed as 0.27 [8]. The mixing process of ingredients for concrete is adopted as per the work of [8].

\subsection{Mix design}

Geo-polymer concrete can be manufactured by adopting the conventional techniques used in the manufacture of Portland cement concrete and the procedure is as follows:

Table No. 1: Physical properties of Materials

\begin{tabular}{|c|c|c|}
\hline S.No. & Property & Specific gravity \\
\hline 1. & Fly-ash & 1.78 \\
\hline 2. & GGBS & 2.70 \\
\hline 3. & M-sand & 1.7 \\
\hline 4. & Slag-Sand & 2.27 \\
\hline 5. & Coarse aggregate & 2.73 \\
\hline
\end{tabular}

Table 2: Mix design adopted for various trials

\begin{tabular}{|c|c|c|c|c|}
\hline Materials & KF60 & KF70 & KF60 & KF70 \\
\hline Fly ash $\mathrm{kg} / \mathrm{m}^{3}$ & $238=13.2 \%$ & $302=16.8 \%$ & $238=13.2 \%$ & $302=16.8 \%$ \\
\hline GGBS $\mathrm{kg} / \mathrm{m}^{3}$ & $158=8.8 \%$ & $94=5.2 \%$ & $158=8.8 \%$ & $94=5.2 \%$ \\
\hline Coarse Aggregate kg/m 3 & $630=35 \%$ & $630=35 \%$ & $630=35 \%$ & $630=35 \%$ \\
\hline $\mathrm{M}-$ sand $\mathrm{kg} / \mathrm{m}^{3}$ & $346=19.2 \%$ & $346=19.2 \%$ & $346=19.2 \%$ & $346=19.2 \%$ \\
\hline $\mathrm{Slag}$ sand $\mathrm{kg} / \mathrm{m}^{3}$ & $230=12.8 \%$ & $230=12.8 \%$ & - & - \\
\hline $\mathrm{NaOH}$ Solution $\mathrm{kg} / \mathrm{m}^{3}$ & $36=2 \%$ & $36=2 \%$ & $36=2 \%$ & $36=2 \%$ \\
\hline $\mathrm{Molarity}$ of $\mathrm{NaOH}$ & $6 \mathrm{M}$ & $6 \mathrm{M}$ & $6 \mathrm{M}$ & $6 \mathrm{M}$ \\
\hline $\mathrm{Na}$ SiO 3 Solution $\mathrm{kg} / \mathrm{m}^{3}$ & $72=4 \%$ & $72=4 \%$ & $72=4 \%$ & 0.38 \\
\hline $\begin{array}{c}\text { Water to geo polymer } \\
\text { solids ratio }\end{array}$ & 0.38 & 0.38 & 0.38 & 0.27 \\
\hline $\begin{array}{c}\text { Alkaline solution to } \\
\text { Binder ratio }\end{array}$ & 0.27 & 0.27 & 0.27 & $90=5 \%$ \\
\hline \begin{tabular}{c} 
Extra Water kg $/ \mathrm{m}^{3}$ \\
\hline
\end{tabular} & $90=5 \%$ & $90=5 \%$ & $90=5 \%$ & \\
\hline
\end{tabular}

Table 3: Adopted mix design KF : GGBS 70:30

\begin{tabular}{|c|c|}
\hline Materials & Quantity in $\mathrm{Kg} / \mathrm{m}^{3}$ \\
\hline Fly ash $\mathrm{kg} / \mathrm{m}^{3}$ & 238 \\
\hline GGBS $\mathrm{kg} / \mathrm{m}^{3}$ & 158 \\
\hline Coarse Aggregate $\mathrm{kg} / \mathrm{m}^{3}$ & 630 \\
\hline $\mathrm{M}$-sand $\mathrm{kg} / \mathrm{m}^{3}$ & 346 \\
\hline Slag sand $\mathrm{kg} / \mathrm{m}^{3}$ & 230 \\
\hline $\mathrm{NaOH}$ Solution $\mathrm{kg} / \mathrm{m}^{3}$ & 36 \\
\hline $\mathrm{Na} 2 \mathrm{SiO} 3$ Solution $\mathrm{kg} / \mathrm{m}^{3}$ & 72 \\
\hline
\end{tabular}

Sabarish Patil et al., 


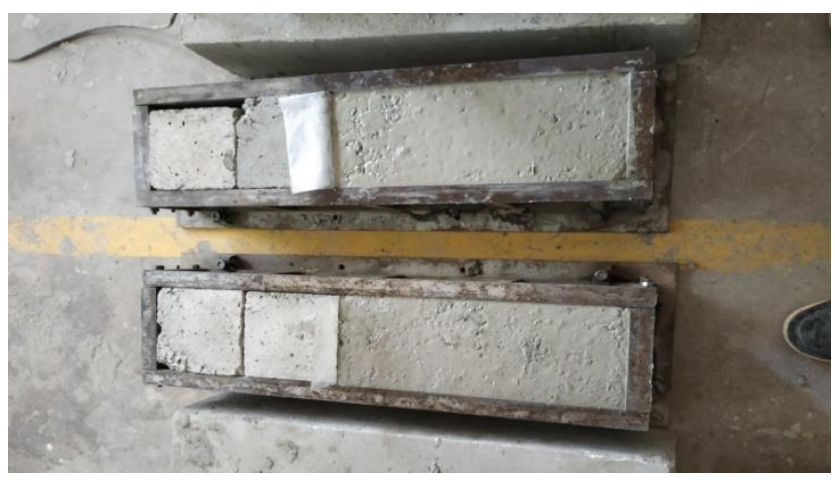

Figure 3 Block Mould

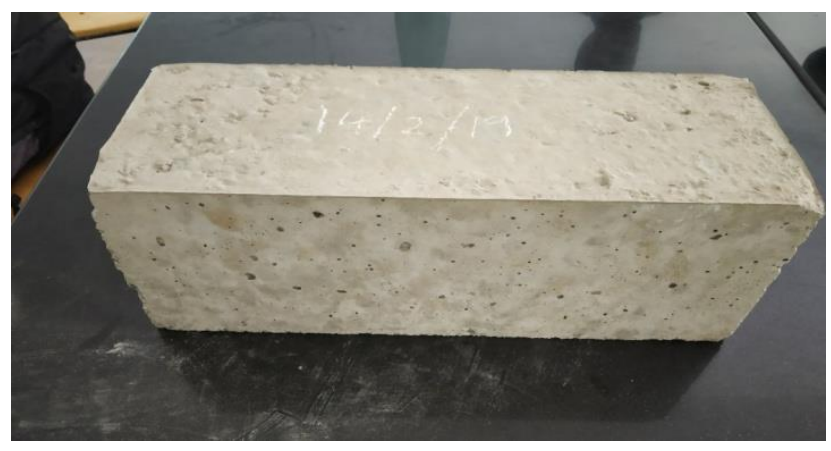

Figure 4 GPC Block

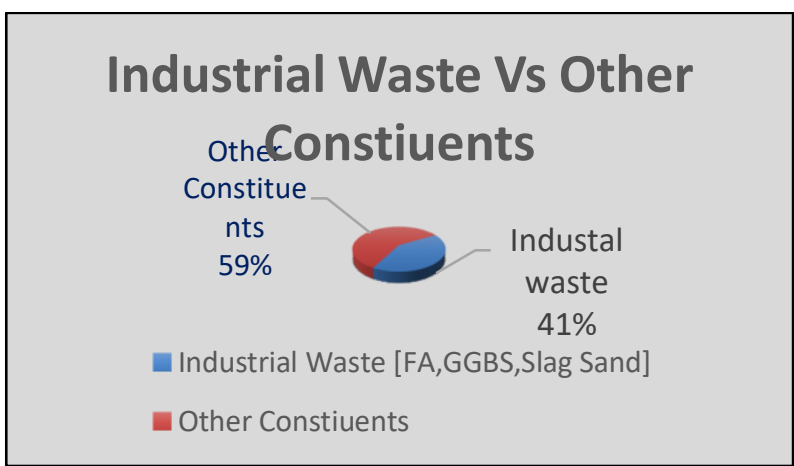

Figure 5: Industrial waste utilization v/s other constituents in GPC blocks

After all trial mix design, the following mix design is adopted because the optimum consumption of fly-ash and GGBS is achieved and hence the cost and sustainable properties are also achieved.

\section{RESULTS AND DISCUSSIONS}

7.1. Compressive Strength: The test procedure for finding a compressive Strength of geo-polymer block is adopted from IS 3495-1992 Part-I. Here, Figure-2 shows the compressive strength of geo-polymer concrete specimen at ambient temperature at 3 and 7 days of ratio fly-ash: GGBS is 70:30.

Attributes from the graph: CC block: Cement Concrete block, GPC block: Geo-Polymer Concrete block.
From the fig 5, we come to the know that the compressive strength for GPC block is 3 times higher than conventional cement concrete block which makes it high strength.

7.2 Water Absorption: The test procedure is done according to IS 2185 part 1 . The test specimens shall be completely immersed in water at room -temperature for $24 \mathrm{~h}$. They shall be removed from the water and visible surface water being removed with a damp cloth and immediately weighed. All specimens shall be dried in a ventilated oven at $100{ }^{\circ} \mathrm{C}$ to $115{ }^{\circ} \mathrm{C}$ for not less than $24 \mathrm{~h}[14,18]$.

As per IS-2185: 2005 part 1, 24-hour water absorption should be more than $10 \%$ for individual blocks. Geo-

Sabarish Patil et al., 
polymer paver blocks had an average of $1.531 \%$. Thus all blocks met the specification.

7.3 Density test: The density of concrete block is defined as the ratio of Mass by Volume. The mass of the block is measured at the room temperature of $27 \pm 2{ }^{\circ} \mathrm{C}$ [18].

Three blocks taken at random from the samples selected, shall be dried to constant mass in a suitable oven heated to approximately $100^{\circ} \mathrm{C}$. After cooling the blocks to room temperature, the dimensions of each block shall be measured in centimeters (to the nearest millimeter) and the overall volume computed in cubic centimeters [12]. The block shall then be weighed in $\mathrm{kg}$ (to the nearest $10 \mathrm{~g}$ ) and the density of each block calculated as follows:

The average density of the geo-polymer concrete block obtained is $1965 \mathrm{~kg} / \mathrm{m}^{3}$. This density is comparable to the low density blocks available in market.

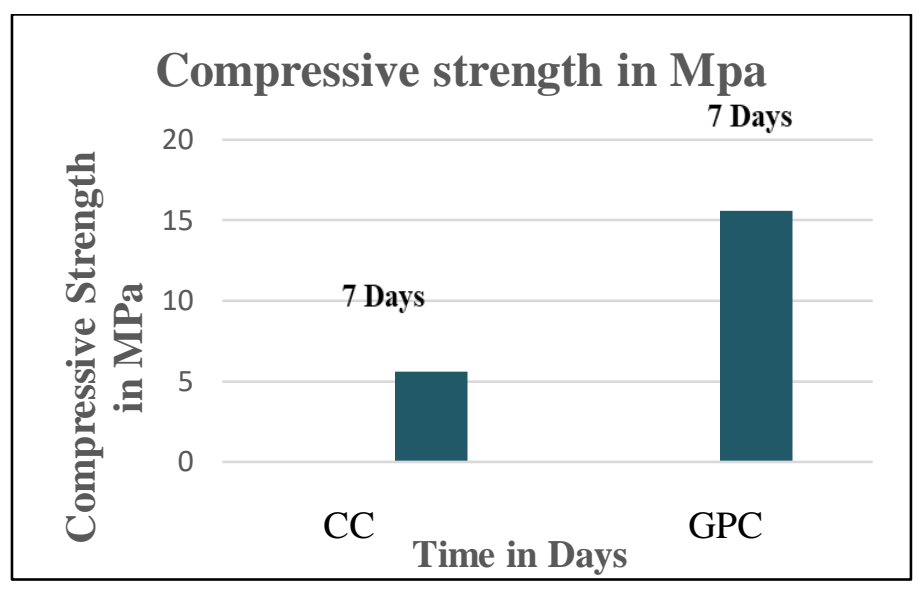

Fig 6: Graph showing compressive strength of GPC block of ratio 70:30

Table 4: Water absorption of Geo-Polymer blocks

\begin{tabular}{|c|c|c|c|c|c|}
\hline $\begin{array}{c}\text { Mould } \\
\text { no. }\end{array}$ & Grade & $\begin{array}{c}\text { Dry } \\
\text { weight(Kg) }\end{array}$ & $\begin{array}{c}\text { Wet } \\
\text { weight(Kg) }\end{array}$ & $\begin{array}{c}\text { Oven Dry } \\
\text { weight(Kg) }\end{array}$ & $\begin{array}{c}\text { Water } \\
\text { absorption } \\
\text { (\%) }\end{array}$ \\
\hline 1 & KF70 & 20.71 & 20.94 & 20.63 & 1.503 \\
\hline 2 & KF70 & 20.84 & 21.08 & 20.76 & 1.541 \\
\hline 3 & KF70 & 20.81 & 20.98 & 21.31 & 1.549 \\
\hline \multicolumn{7}{|r|}{} & Average & 1.531 \\
\hline
\end{tabular}

Table 5: Density of Geo-polymer Blocks

\begin{tabular}{|c|c|c|c|}
\hline $\begin{array}{c}\text { Block } \\
\text { no. }\end{array}$ & Weight (kg) & Volume $\mathbf{( m}^{\mathbf{3})}$ & $\begin{array}{c}\text { Density } \\
\mathbf{( k g / \mathbf { m } ^ { 3 }} \mathbf{~}\end{array}$ \\
\hline 1 & 17.65 & $9.00 \times 10^{-3}$ & 1961.11 \\
\hline 2 & 17.75 & $9.00 \times 10^{-3}$ & 1972.22 \\
\hline 3 & 17.68 & $9.00 \times 10^{-3}$ & 1964.44 \\
\hline \multicolumn{2}{|r}{} & Average & 1965.92 \\
\hline
\end{tabular}

Table 6: Cost analysis

\begin{tabular}{|c|c|c|c|c|}
\hline Sl.No & Particulars & $\begin{array}{c}\text { Volume in } \\
\mathbf{k g} / \mathbf{m}^{\mathbf{3}}\end{array}$ & $\begin{array}{c}\text { Rate in } \\
\text { rupees }\end{array}$ & $\begin{array}{c}\text { Rate in } \\
\text { rupees } / \mathbf{m}^{\mathbf{3}}\end{array}$ \\
\hline 1 & Fly-ash & 302 & $350 /$ tonne & 105.7 \\
\hline 2 & GGBS & 94 & $2500 /$ tonne & 235 \\
\hline 3 & M-sand & 356 & $700 /$ tonne & 249 \\
\hline 4 & Slag sand & 238 & $150 /$ tonne & 35.7 \\
\hline 5 & Coarse aggregate & 630 & $650 /$ tonne & 409.5 \\
\hline 6 & NaOH & 36 & $12.2 / \mathrm{kg}$ & 439.2 \\
\hline 7 & Na2SiO3 & 72 & $21 / \mathrm{kg}$ & 1512 \\
\hline & & & Total cost $=$ & $2986 /-$ \\
\hline
\end{tabular}

Sabarish Patil et al., 


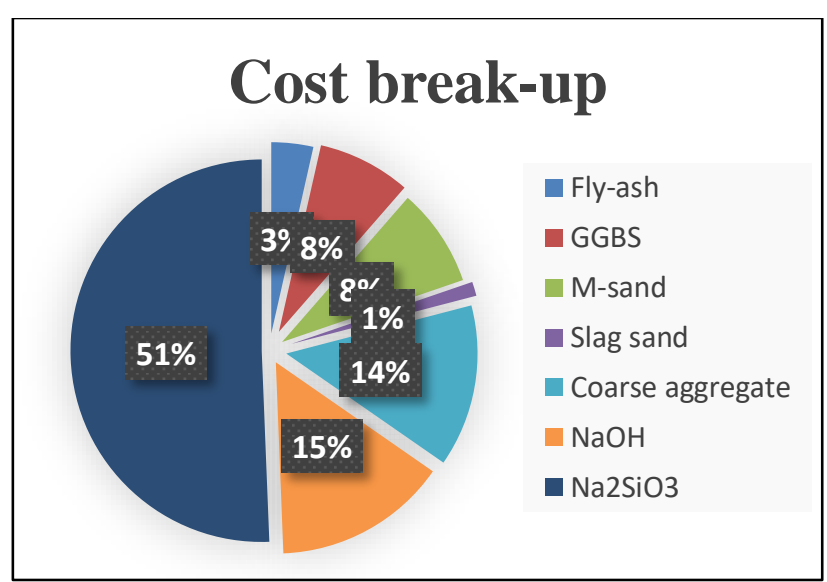

Fig 7: Graph showing Cost break-up of GPC block

\subsection{Cost analysis of the block}

The total cost of GPC block per $\mathrm{m}^{3}$ is Rs. 2986/-. Hence, the cost of 1 block is Rs.26 approx.

The cost estimated for conventional cement concrete blocks manufactured locally cost Rs $3219 /-$ per $\mathrm{m}^{3}$. The cost of 1 block is Rs 29 approximately. Therefore, the GPC block cast is cheaper than CC block. Thus the blocks are cost effective.

\section{How GPC block is different from cement concrete block?}

6.1. Compressive Strength: The Compressive strength of geo-polymer concrete block after 7 days is 15.5 $\mathrm{MPa}$ whereas the compressive strength for cement concrete block after 7 days varies from 7-8 $\mathrm{MPa}$. This shows that geo-polymer concrete blocks are 2 times stronger than cement concrete blocks.

6.2. Water absorption: Water absorption for geopolymer concrete blocks for 1 day varies from 1.5$1.8 \%$. For cement concrete blocks it varies from $8-8.5 \%$ [8]. This shows that geo-polymer concrete blocks prevents the absorption of water and protects from increase in weight and collapse.

6.3. Surface finish and sharp edges: Geo-polymer concrete block posses' smooth surface finish and sharp edges which reduces the consumption of plaster and reduces cost, whereas cement concrete blocks poses' rough surface finish and rounded edges making it less efficient in application.

6.4. Cost effective: The cost for 1 geo-polymer concrete block on site is Rs 22-23.5/- and cost of 1 cement concrete block is Rs 28-28.5/-. Thus geopolymer concrete blocks are cost effective and give both tangible and intangible benefits.

6.5. Sustainability: Geo-polymer concrete blocks use $35-40 \%$ of industrial waste materials like fly-ash, GGBS and slag sand thus making them more sustainable than cement concrete block which use 15-18\% [16].

\section{CONCLUSION}

The average compressive strength of Geo-polymer concrete block for 7-day ambient curing is $13.89 \mathrm{MPa}$ which complies with IS 2185 (part1):2005. The cost of the block varies from Rs 25-26/-, which is cheaper than cement concrete block, thus GPC blocks have both tangible and intangible benefits. Geo-polymer concrete block have an average water absorption of $1.53 \%$ which is better than that of conventional cement concrete block. The average density of Geo-polymer block is $1965 \mathrm{~kg} / \mathrm{m}^{3}$. The block has good surface finish and sharp edges, which saves the plaster and other additives applied to walls. There is no requirement of water for curing of geo-polymer concrete block, thus it saves water as well as curing time. Due to utilization of large quantity of industrial waste materials to manufacture this block, makes it more sustainable and commercially viable. The block has good surface finish and sharp edges, which saves the plaster and other additives applied to walls. There is no requirement of water for curing of geo-polymer concrete block, thus it saves water as well as curing time. Due to utilization of large quantity of industrial waste materials to manufacture this block, makes it more sustainable and commercially viable.

\section{REFERENCES}

[1]. Davidovits, J., 1989. Geo-polymers and Geopolymeric Materials, Journal of Thermal Analysis, vol.35, pp 429-431.

[2]. Hardjito, D., Rangan, B. V., 2005. Development and Properties of Low-Calcium Fly ash-Based Geopolymer Concrete, Research Report GC 1, Curtin University of Technology, Perth, Australia, pp 1-92.

[3]. Raijiwala D.B and Patil H.S,. 2011. "Geopolymer Concrete: A Concrete Of Next Decade", Journal of Engineering And Studies ,Vol 2, Issue2, pp 19-25.

Sabarish Patil et al., 
[4]. Abdul Aleem, M.I., P.D. Aumairaj,. 2012. "Geopolymer Concrete Review", Int Journal of Engineering Sciences and Emerging Technology, vol1, issue 2, pp 118-122,

[5]. Djwantoro Hardjito, Steenie E. Wallah, Dody M. J. Sumajouw, and B.Vijaya Rangan, 2004. "On the Development of Fly Ash-Based Geopolymer Concrete", ACI Materials journal, title no. 101M52, pp 467-472.

[6]. Didar Singh Cheema and N.Lloyd,. 2014. Blended Low Calcium Fly Ash Geopolymer Concrete,Int Conference On Geological And Civil Engineering,62(13), pp-65-69. Kolli Ramujee and Potharaju Malasani,. 2014. Development of Low Calcium Flyash Based Geopolymer Concrete, Int. Journal of Engineering and Technology, 6(1), pp 1-4.

[7]. Tejas Ostwal, Manojkumar Chitawadagi,. Jun2014. 'Experimental Investigations on Strength, Durability, Sustainability \& Economic Characteristics of Geopolymer Concrete Blocks, International Journal of Research in Engineering and Technology (IJRET), pp 115-122.

[8]. Sakthivel, P., 2016. Experimental Investigation on Fly ash Based Geopolymer Bricks. International Journal of Application or Innovation in Engineering \& Management (IJAIEM), 5, pp 216-227.

[9]. Dinesh, S., R Devaki and S Shrimathi,. 2017. Experimental Investigation on Paver Block using Geopolymer Concrete. International Journal of Engineering Research and Modern Education, pp 47-50.

[10]. Murthy, R., and D Subbarao,. 2014. Fly ash based Geopolymer concrete bricks for building construction, Indian Concrete Institute Journal (ICI), pp 29-33.

[11]. Patankar S. V, Jamkar, S and Ghugar Y, 2013. Effect of Water to Geopolymer Binder Ratio on Production of Fly Based Geopolymer Concrete, International Conference on Recent Trends In Engineering and Tech, 2, pp 876-881.

[12]. Manoj Kumar and Hanitha, P. 2016. Geopolymer Concrete Using Flyash and GGBS as Replacement of Cement, Journal on Mechanical and Civil Engineering, vol.13, issue 6, pp 85-92.

[13]. Venugopal, K. Radhakrishna and Vinod S,. 2016. Development of Alkali Activated Geopolymer Masonry Blocks. IOP Conference Series: Materials Science and 149 (2016) 012072.

[14]. Vijaysankar, P., Anuradha, R., Sreevidya, Venkata subramani,. 2013. Durability Studies of Geopolymer Concrete Solid Blocks. International Journal of Advanced Scientific and Technical Research, 3(2), pp 1-12.

[15]. Senthilkumar,. 2015. Study of properties of geo polymer eco bricks, Open Journal of Civil Engineering, Bharath University, Published Online, pp 139-148.

[16]. Shabarish Patil, Veeresh Karikatti and Manojkumar Chitawadagi,. 2018. Granulated Blast-Furnace Slag (GGBS) based Geopolymer Concrete - Review. International Journal of Advanced Science and Engineering. 5(1) pp 879-885.

[17]. IS 2185(Part 1):2005. Indian Standard on Concrete Masonry Units - Specification: Hollow and Solid Concrete Blocks. Bureau of Indian Standards.

All (C) 2019 are reserved by International Journal of Advanced Science and Engineering. This Journal is licensed under a Creative Commons Attribution-Non Commercial-ShareAlike 3.0 Unported License.

Sabarish Patil et al., 